\title{
Polyamines, peroxidase and proteins involved in the senescence process
}

\author{
Marcos Ribeiro da Silva Vieira" ${ }^{1 *}$ Fernando Jose Freire ${ }^{2}$, Damiana Cleuma de \\ Medeiros ${ }^{3}$ Fabiana Bezerra Moura ${ }^{1}$, Thialla Laranjeira Amorim ${ }^{1}$ and Adriano Nascimento dos \\ Simões ${ }^{1}$
}

${ }^{1}$ Universidade Federal Rural de Pernambuco, Unidade Acadêmica de Serra Talhada, CEP: 59909-460, Serra Talhada, PE, Brasil.

${ }^{2}$ Departamento de Agronomia, CEP: 52171-900, Recife, PE, Brasil'

${ }^{3}$ Instituição: UFRN - Unidade Acadêmica Especializada em Ciências Agrárias, Departamento de Agropecuária, Macaíba, RN, Brasil.

Accepted 13 March, 2013

\begin{abstract}
Senescence is the natural aging process at the cellular level or range of phenomena associated with this process. The objective of this review was to show the involvement of substances that may be related to senescence in plants, such as polyamines, peroxidase and proteins. These substances were related with the terminal stages of development of various plant organs (leaves, flowers, roots).
\end{abstract}

Key words: Flowers, putrescine, spermidine, spermine, reactive oxygen species.

The plants are generally classified as highly products perishable, the ephemeral nature of the different tissues that form, the high activity respiratory and the low-carbohydrate reserves (Nowak and Rudnicki, 1990; Skutnik et al., 2001). After harvesting occur flowers' biochemical, structural and physiological change processes leads to tissue disorganization and disintegration of organs which promote senescence. The polyamines [putrescine (PUT), spermidine (SPD) and spermine SPM)], classified as plant growth regulators, are related to different responses physiologically, such as senescence and stress. In plants, the diamine and putrescine synthesizes from arginine and ornithine. The putrescine is converted to spermidine and spermine by successive transfers of one or two aminopropyl groups via SAM (S-adenosyl methionine) (Lima et al., 1999).

Other substances related to senescence such as pero- xidases, are enzymes that typically catalyze reactions using oxi-reduction hydrogen peroxide $\left(\mathrm{H}_{2} \mathrm{O}_{2}\right)$ as electron acceptor to catalyze different oxidative reactions (Blokhina et al., 2003) and proteins (Sugawara et al., 2002; Azeez et al., 2007), whose synthesis is characterized by high and rapid adaptability molecular and physiologically functional with respect to the medium (Larcher et al., 2000).

\section{POLYAMINES}

The polyamines (PAs) are aliphatic molecules of low molecular weight present in all organisms. The main PAs found in the higher plants are PUT, SPD and SPM occurring in free form or conjugated to phenolic acids and low molecular weight molecules (Bouchereau et al., 1999;

${ }^{*}$ Corresponding author. E-mail: m.r.s.v@hotmail.com.

Abbreviations: PAs, Polyamines; PUT, putrescine; SPD, spermidine; SPM, spermine; SAM, decarboxylated S-adenosyl methionine ACC, oxidase of 1-aminocyclopropane-1-carboxylic acid; ADC, arginine decarboxylase activity; SAMDC, SAM decarboxylase; ROS, reactive oxygen species; POD, peroxidase; HR, hypersensitive response, IAA, indole-3-acetic acid; PCD, programmed cell death. 
Kuznetsov et al., 2006). In addition to biosynthesis and conjugation, the oxidative degradation is one way of regulating the PAs levels (Kusano et al., 2008). In plants, the PAs are located not only in the cytosol but also in the organelles, such as mitochondria, chloroplasts and vacuoles (Kumar et al., 1997). Its synthesis is initiated by two different routes: the PUT is formed directly from ornithine or indirectly by arginine and the formation of SPM occurs by adding a decarboxylated S-adenosyl methionine (SAM) group added to PUT. The formation of SPM occurs by adding another decarboxylated SAM (Coruzzi and Last, 2000).

The presence of positive charges on the molecules of PAs allows their electrostatic binding to cellular macromolecules, including DNA, RNA, proteins, chromatin and may cause stabilization or destabilization of these macromolecules (Kusano et al., 2008). Thus, they are involved in fundamental cellular processes including gene expression regulation, signal modulation and cell proliferation and membrane stabilization (Tabor and Tabor, 1984; Cohen, 1998; Igarashi and Kashiwagi, 2000).

Recent studies show that PAs have function in modulating many physiological processes in plants, such as cell division and differentiation, organogenesis, embryogenesis and tolerance to biotic and abiotic stress (Bouchereau et al., 1999; Crozier et al., 2001; Martin-Tanguy, 2001; Baisand Ravishankar, 2002; Silveira et al., 2004; Silveira et al., 2006; Santa-Catarina et al., 2006; Groppa and Benavides, 2008).

Some plants use the mechanism called osmotic adjustment to tolerate the effects of abiotic stresses, which allows the cell to maintain its metabolic functions even in adverse environmental conditions, thus promoting tolerance to stress and maintain relatively high osmotic potential (Bayuelo-Jiménez et al., 2002). This mechanism enables the cell to accumulate substances called compatible osmolytes, which preserve cell integrity resulting in the continuation of vital activities to plant growth and development (Bray et al., 2001). There is evidence that the PAs stabilize the membrane and retard senescence (Smith, 1985). SAM can be turned successively into aminopropyl-carboxylic acid and ethylene (Slocum, 1984), once the PAs and ethylene compete for the same precursor (Bouchereau et al., 1999; Pandey et al., 2000).

The PAs inhibit the ethylene production by regulating the activity of synthase and oxidase of 1-aminocyclopropane-1-carboxylic acid (ACC) (Lee et al., 1997), while ethylene alters the PAs formation by reducing the arginine decarboxylase activity (ADC) and SAM decarboxylase (SAMDC) (Roustam et al., 1994). Changes in PAs levels and ethylene during senescence have been reported in some plants such as plum (de Dios et al., 2006) and Hibiscus syriacus L. (Seo et al., 2007). Li and Wang (2004) observed that between ethylene and polyamines, there is metabolic competition only under high stress conditions.

The PAs concentration may vary by plant organ, maturi- ty and post-harvest treatment (Carbonell et al., 2000; Chattopadhayay et al., 2002; Nayyar and Chander, 2004). Pomegranates show higher levels of PAs during cold storage; however, the main change occurred for SPM (Mirdehghan et al., 2007). PUT accumulation was also noted in pepper, cucumber, zucchini and citrus (orange and lemon) during exposure to cold chamber (Serrano et al., 1998; Martínez-Romero et al., 2003). In Faroe chrysanthemum stems Vieira et al. (2010) observed decreases in the levels of PAs throughout the cold storage. In several species, the PAs increase was correlated with the reduction of injuries caused by such stress (Kramer and Wang, 1989; Wang and Ji, 1989). It has been suggested that the accumulation of polyamines in tissues can confer more tolerance to various types of stresses due to these amines act in the removal of reactive oxygen species and also assist the stabilization of cell membranes (Larher et al., 2003; Groppa and Benavides, 2008).

High temperature also causes reduction in cell division and this effect may be linked to its action on the Pas. Under high temperatures would occur reduction in the concentration of these polyamines, affecting cell division (Poljakoff-Mayber and Lerner, 1994). In post-harvest of cloves kept at $21^{\circ} \mathrm{C}$, Serrano et al. (1998) observed increase in PUT content and decrease in SPD. In addition to PAs, other substances may be related to sensecence in plants such as peroxidase and proteins.

\section{PEROXIDASE}

Plants produce reactive oxygen species (ROS) in various metabolic processes, when they suffer some kind of stress (Jin et al., 2006). Thus, ROS may be generated during the post-harvest phase of flowers, which according to Shigeokaet al. (2002) would cause oxidative damage in plants. The accumulation of these ROS could promote damage to lipids, proteins, among others, forming toxic products (Pennycooke et al., 2005). Plants have antioxidative enzymes such as peroxidase (POD) that diminish the damage caused by excess peroxides (Scandalios, 1993). The POD's (EC 1.11.1.7) contain a heme prosthetic group (ferriprotoporphyrin IX) and in the catalytic process transiently oxidize the ferric ion $\left(\mathrm{Fe}^{3+}\right)$ to the higher valence states $\left(\mathrm{FE}^{4+}\right.$ or $\mathrm{FE}^{5+}$ ). In the reaction involving the POD, the electron donor can be ascorbate, amines and other organic compounds. The oxidation product show in many cases, intense staining (Richardson and Hyslop, 2000).

The POD can be considered a stress enzyme stimulated by low temperatures (El-Hilari et al., 2003). In baroapotato, Menolli et al. (2008) observed increased activity of the enzyme POD until the 7th day of storage at $5^{\circ} \mathrm{C}$. Martinez-Téllez and Lafluente (1993) and El-Hilari et al. (2003) analyzing orange fruitsof Navelina cultivar stored at $1,2.5,5$ and $10^{\circ} \mathrm{C}$ for 60 days and Mandarin' 'Fortune" stored at 4 and $8^{\circ} \mathrm{C}$ for 4 weeks, verified changes in the 
POD activity. Zauberman et al. (1985) did not detect variation in the POD activity in avocados 'Fuerte' stored at 0,2 and $5^{\circ} \mathrm{C}$ for up to 18 days.According to Yang and Hoffman (1984), storage at low temperatures causes induction of various enzymes such as POD, which can convert the acid 1-aminocyclopropane-1-carboxylic (ACC) into ethylene. At higher temperatures, Costa (2009) did not observe a standard trend for POD activity in stems of Heliconia Bilhai at 12 and $19^{\circ} \mathrm{C}$. Responses of this nature were also obtained by Vieira et al. (2010) in Faroe chrysanthemum stems at 10 and $25.2^{\circ} \mathrm{C}$.

The POD is also involved in various reactions such as oxidation of phenols, oxidation of indole-3-acetic acid (IAA), bonds of polysaccharides, wound healing, defense against pathogens in the hypersensitive response (HR), lignin and suberin synthesis to the cell wall thickening, regulation of cell elongation and senescence (Quiroga et al., 2000; Silva, 2000; Kao, 2003; Campos et al., 2004). Hossain et al. (2006) report that increased levels of peroxides could be a programmed regulation of the activity of POD enzymes which seems to be a prerequisite for the onset of petals senescence. Bartoli et al. (1997) observed increased POD activity in Chrysanthemum morifolium Ram petals during senescence and related to defense against oxidant molecules that promote membrane damage.

The POD can occur in cells programmed for death and in flowers the deterioration is certainly programmed, it is not reversible and inevitably leads cells to death (Rogers, 2006). The substances deposited on the cut surface of flowers, as well as tyloses, can migrate into the xylem vessels, serving as barrier for microorganisms at the time they cause obstruction, preventing the water absorption. The formation of such substances, according to Vaslier and Van Doorn (2003), probably is involved in the ethylene synthesis and action of enzymes such as POD.

The POD enzyme is involved in vascular blockage of some species of flowers by oxidation of p-coumaryl alcohol, coniferyl and sinapil, which are precursors of lignin. Lignin is a compound that is part of the secondary metabolism of plants and, although providing support and structuring to water transport through the xylem, it may function as a protective mechanism against pathogen attack in case of stress by depositing on the cut surface preventing also the entry of water into vases (Boerjan et al., 2003). Loubaud and Van Doorn (2004) concluded that the blockage in Astilbe stems, since once developed in flowers kept in humid and dry storage, however, in roses cv. Red One and Viburnum opulusthe blockage observed in these stems was apparently related to the presence of bacteria in the xylem.

\section{PROTEINS}

Proteins are linear polymers of amino acids (macromolecules) with molar mass ranging from hundreds to thousands of Daltons $\left(1 \mathrm{Da}=1.661 \times 10^{24} \mathrm{~g}\right)$. Only about 20 amino acids are found in animal and plant proteins, and these are combined in myriad ways to form a variety of different proteins (Magalhães, 2008). An amino acid has a carboxylic group and an amino group in protein molecules and they are responsible for peptide bonds formation, except the $\mathrm{N}$ and $\mathrm{C}$ terminals of the protein. Each amino acid has two ionization constants, which represent the ionization constants of 1-amino and 1-carboxylic acid groups of the free amino acid. However, some have more than two pKa values, once they have other ionizable groups in their chains. The net charge of a protein molecule in aqueous solution depends on the ionization constant of the constituent amino acid side chains and the solution $\mathrm{pH}$ (Melvin, 1987).

The proteins are divided into a plant cell among various organelles and have specific functions. As an example, a small amount of proteins may be found in the cell wall and part of them consists of enzymes that initiate formation reactions, remodeling or breakdown of the wall structure. The chloroplast has a double membrane and there are transport proteins in the outer layer of this membrane (Newton et al., 2004). The synthesis of proteins is the central function of all cells. In its absence, growth and maintenance of organs cease and this represents a limiting factor to the growth rate of plants (Porter and Lawlor, 1991). According to Larchjer et al. (2000), the protein synthesis is characterized by high and rapid capability of molecular, functional and physiologic adaptation relative to the medium.

Changes in the levels of proteins have been associated in part as a result of synthesis of "new" specific proteins during senescence (Woodson and Handa, 1987), such as the ribonucleases, the $\beta$-glucosidases and proteases (Sood et al., 2006).The knowledge of the synthesis and the nature of modifications that proteins regulate have important implications for successful handling of longevity of the flowers (Woodson and Handa, 1987). The percentage of total protein is a data that evaluates the plants conditions in the field and post-harvest. Sood et al. (2006) noted that the protein content was higher in young seedlings and lower in the stages of maximum development. Drevdahl and Thimann (1977) observed decrease in protein contents during development in oat plants. In Sandersonia petals (Eason et al., 2002) and Dendrobium cv. Khao Sanan (Lerslerwong et al., 2009), there was decreased protein content during senescence. This response was also observed in leaves and flowers of Faroe Chrysanthemum post-harvest (Vieira et al., 2010), while Laschi (2000) observed increased proteinsin rose stems. Souza (2008) reported decreases in protein levels between the third and tenth day of assessment in inflorescences of Heliconia Golden Torch. This author studied the percentage of proteins in heliconia bilhai and observed $7.0 \%$ increase from the harvest day and the four days of storage, followed by decreases until the tenth day.

The reduced proteins can be attributed to the action of 
proteases. Elanchezhian and Srivastava (2001) suggested that the decreased protein contents in chrysanthemum petals during senescence was due to the synthesis inhibition and increased protein degradation by proteases, resulting in loss of functional capacity of the membranes, increased output of ions and finally senescence and death of tissues. Through studies on the programmed cell death (PCD), it was shown that proteases increased and their relationship with senescence as a possible regulator of programmed death in plant cells (Gerreiro et al., 1998; Gietl and Schimid, 2001).

Proteins play a critical role in modulating plant response to stress. Saliveit (2000) and Thomashow (2001) claim that the low temperature during storage induces changes in protein content. Ferguson et al. (1988) also mentions that high temperature can directly or indirectly injure plant proteins by inactivating enzymes, changing the conformation of peptides or disrupting membrane complexes. Within this field, important advances have been made in understanding the plant response to stress.

\section{REFERENCES}

Bais HP, Ravishankar GA (2002). Role of polyamines in the ontogeny of plants and their biotechnological applications.Plant Cell, $\mathrm{T}$ and $\mathrm{O}$ Culture. 69:1-34.

Bar|toli GC, Guaiamet JJ, Montaldi ER (1997). Ethylene Production and Responses to Exogenous Ethylene in Senescing Petals of Chrysanthemum morifolium RAM cv. Unsei.Plant Science. 124:1521.

Bayuelo-Jimenez J, Debouck DG, Lynch JP (2002). Salinity tolerance in Phaseolus species during early vegetative growth. Crop Sci. 42:2184-2192.

Boerjan W, Ralph J, Baucher M (2003). Lignin biosynthesis. Annual R.P. Biology. 54:519-546.

Bouchereau A, Aziz A, Larher F, Martin-Tanguy J (1999). Polyamines and environmental challenges: recent development. Plant Science. 140:103-125.

Bray EA, Bailey-Serres J, Weretilnyk E (2001). Responses to abiotic stress. In: Buchanan, B.; Gruissem, W.; Jones, R. (Eds). Biochemistry \& molecular biology of plants.American Society of Plant Physiologists. 22:1167-1168.

Campos AD, Ferreira GA, Hampe MMV, Antunes IF, Brancão N, Silveira EP, Osório VA, Augustin E (2004). Atividade de peroxidase e polifenoloxidase na resistência do feijão à antracnose. Pesquisa Agropecuária Brasileira.39(7):637-643.

Carbonell BA, Valero GD, Martínez RD, Serrano MM, Burló CF (2000). Polyamines: biosynthesis, metabolism, and their role in ripening and postharvest handling of fruits. Food Science and T. International. 6:85-95.

Chattopadhayay MK, Tiwari BS, Chattopadhayay G, Bose A, Sengupta DN, Ghosh B (2002). Protective role of exogenous polyamines on salinity stressed rice (Oryza sativa) plants. Physiologia Plantarum. 116:192-199.

Coruzzi G, Last R (2000). Amino acids. In: Buchanan, BB; Gruissem, $\mathrm{W}$; Jones, RL Biochemistry and Molecular Biology of Plants. American Society of Plant Physiologists. 358-410.

Costa AS (2009). Conservação pós-colheita, sintomas e respostas fisiológicas da senescência e injúria por frio em hastes florais de Heliconia bihai(L). 83f. Tese (Doutorado em Botânica) - Universidade Federal Rural de Pernambuco, Recife.

Crozier A (2001). Biosynthesis of hormones and elicitor molecules. In: Buchanan, B.; Gruissem, W.; Jones, R. (Eds). Biochem. Mol. Biol. Plants. Amr. Soc. Plant Physiol. 911-915.

de Dios P, Matilla AJ, Gallardo M (2006). Flower fertilization and fruit development prompt changes in free polyamines and ethylene in damson plum (Prunusinsititial.). J. Plant Physiol. 163:86-97.

Drevdahl RA, Thimann KV (1977). Proteases of senescing oat leaves I. purification and general properties. Plant Physiol. 59:1059-1063.

Eason JR, Ryan JD, Pinkney TT, O'donoghue EM (2002). Programmed cell death during flowers senescence: isolation and characterization of cysteine proteinases from Sandersonia aurantiaca. Funct. Plant Biol. 29(60):1055-1064.

Elanchezhian R, Srivastava GC (2001). Physiology changes during flower senescence. Biol. Plant. 44(3): 411-415.

El-Hilari F, Ail-Oubahou A, Remah A, Akhayat O (2003). Chilling injury and peroxidase activity change in "Fortune" mandarin fruit during low temperature storage. Bulgarian J. Plant Physiol. 29(1-2):44-54.

Ferguson JD, Blannchard T, Galligan DT (1988) Infertility in dairy cattle fed a high percentage of protein degradable in the rumen. J. Anim. Vet. Med. Assoc. 192:659-662.

Gietl C, Schmid M (2001). Ricinosmes: an organelle for development regulated cell death in senescence in plant tissues. Naturwissenschaften. 88:49-58.

Groppa MD, Benavides MP (2008). Polyamines and abiotic stress: recent advance. Amino Acids.34:35-45.

Guerreiro C, Calle M, Reid MS, Valpuesta V (1998). Analysis of the expression of two thioproteinase genes from daylily (Hemerocallisspp) during flower senescence. Plant Mol. Biol. 36: 565-571.

Hossain Z, Mandal AKA, Datta SK, Biswas AK (2006). Decline in ascorbato peroxidase activity-a prerequisite factor for tepal senescence in gladiolus. J. Plant Physiol. 163:186-194.

Igarashi K, Kashiwagi K (2000). Polyamines: mysterious modulators of cellular functions. Biochem. Biopsychol. Res. Commune 271(3):559564.

Jin J, Shan N, Ma N, Bali J, Gao J (2006). Regulation of ascorbate peroxidase at the transcript level is involved in tolerance to postharvest water deficit stress in the cut rose (Rosa hybrida L.) cv. Samantha, Postharvest B Technol. 40(30):236-243.

$\mathrm{Kao} \mathrm{CH}$ (2003). Differential effect of sorbitol and polyethylene glycol on antioxidant enzymes in rice leaves. Plant G. Reg. 39(2):83-89.

Kramer GF, Wang Y (1989). Correlation of reduced chilling injury with increased spermine and spermidine levels in zucchini squash. Journal of Plant Physiology, 76(3):479-484.

Kumar A, Taylor M, Altabella T, Tiburcio A (1997). Recent advances in polyamine research. Trend Plant Sci. 2(4):124-130.

Kusano T, Berberich T, Tateda C, Takahashi Y (2008). Polyamine: essential factors for growth and survival. 228:367-381.

Kuznetsov V, Shorina M, Aronova E, Stetsenko L, Rakitin V, Shevyakova N (2006). NaCl-and ethylene-dependent cadaverine accumulation and its possible protective role in the adaptation of the common ice plant to salt stress.Plant Science.172:363-370.

Larchjer W (2000). Ecofisiologia vegetal.São Carlos: RiMa, p.531.

Larher FR, Aziz A, Gibon Y, Trotel-Aziz P, Sulpice R, Bouchereau A (2003). An assessment of the physiological properties of the socalled compatible solutes using in vitro experiments with leaf discs. Plant Physiol. Biochem. 41(6-7):657-666.

Laschi D (2000). Fisiologia de hastes cortadas de rosa (Rosa sp) cv. Grand Gala. 110 f. Tese (Doutorado em Agronomia/Horticultura) Instituto de Biociência de Botucatu, Universidade Estadual Paulista.

Lerslerwong L, Ketsa S, van Doorn WG (2009). Protein degradation and peptidase activity petal senescence in Dendrobium cv. Khao Sanan. Postharvest Band Technol. 52:84-90.

Lee MM, Lee SH, Park KY (1997). Effects of spermine on ethylene biosynthesis in cut carnation (Diathuscaryophyllus L.) flowers during senescence. J. Plant Physiol. 151:68-73.

Li C, Jiao J, Wang G (2004). The important roles of reactive oxigen species in the relationship between ethylene and polyamines in leaves of spring wheat seedlings under root osmotic stress. Plant Sci. 166:303-315.

Loubaud M, Van Doorn G (2004). Wound-induced and bacteria-induced xylem blockage in roses, Astible, and Viburnum. Postharvest B Technol.32:281-288.

Magalhães CS (2008). Avaliação comparativa de procedimentos de extração de proteínas em plantas medicinais e fitoterápicos e quantificação de metais associados a essas proteínas. 151 f. Tese (Doutorado em Ciências)-Universidade Estadual de Campinas. 
Martinez-Tellez MA, Lafuente MT (1993). Chilling-induced changes in phenylalanine ammonia-lyase, peroxidase, and polyphenol oxidase activities n citrus flavedo tissue. Acta Horticult. 3(43):257-263.

Martínez-Romero D, Serrano M, Valero D (2003). Physiological changes in pepino (Solanummuricatum Ait.) fruit stored at chilling and nonchilling temperatures. Postharvest B Technol. 30:177-186.

Martin-Tanguy $\mathrm{J}$ (2001). Metabolism and function of polyamines in plants: recent development (new approaches). Plant Growth Reg. 34:135-148.

Melvin M (1987). Electrophoresis: analytical chemistry by open learning. London: John Wiley p. 127.

Menolli LN, Finger FL, Puiatti M, Barbosa MJ, Barros RS (2008). Atuação das enzimas oxidativas no escureci-mento causado pela injúria por frio em raízes de batata-baroa. Acta Scientiarum Agronomy.30(1):57-63.

Mirdehghan SH, Rahemi M, Martínez-Romero D, Guillé F, Valverde JM, Zapata PJ, Serrano M, Valero D (2007). Reduction of pomegranate chilling injury during storage after heat treatment: Role of polyamines. Postharvest B. Technol. 44: 19-25.

Nayyar H, Chander S (2004). Protective effects of polyamines against oxidative stree induced by water and cold stress in chickpea. J. Agron. Crop Sci. 190:355-365.

Newton RP, Brenton AG, Smith CJ, Dudley E (2004). Plant proteome analysis by mass spectrometry: princi-ples. Problems, pitfalls and recent developments, Phyto-chemistry. 65(2):1449-1453.

Pandey RK, Maranville JW, Chetima MM (2000). Deficit irrigation and nitrogen effects on maize in a Sahelian environment. II. Shoot growth, nitrogen uptake and water extraction. Agric. Water Mangt.46:1-13.

Pennycooke JC, Cox S, Stushnoff C (2005). Relationship of cold acclimation, total phenolic content and antioxidant capacity with chilling tolerance in petunia (Petunia $x$ hybrid). Environ. Expt. Bot. 53:225-232.

Poljakoff-Mayber A, Lerner HR (1994). Plants in saline environments. In- Handbook of plant and crop stress. Pessarakli, m. (Ed.). Marcel Dekker. New York. 65-96.

Porter JR, Lawlor DW (1991). Plant Growth: interactions with nutrition and environment Cambridge: University of Cambridge Press, $284 \mathrm{p}$.

Quiroga C, Guerreiro C, Botella MA, Barceló A, Amaya I, Medina MI, Alonso FJ, Forchetti SM, Tigier H, Valpuesta V (2000). A tomato peroxidase involved in the synthesis of lignin and suberin. Plant Physiol. 122:1119-1127.

Richardson T, Hyslop DB (2000). Enzimas. In: Fennema, OR (Dir.) Química de los alimentos. Acríbia. 501-503.

Rogers HJ (2006). Programmed cell death in floral organs: How and why do flowers dye? Ann. Bot. 97:309-315.

Roustan JP, Chraibi KM, Latche A, Fallot J (1993). Relationship between ethylene and polyamine synthesis in plant regeneration. In: Pech, JC (Ed.) Cellular and molecular aspects of the plant hormone ethylene. Kluwer Acad. Pub. 365-366.

Saliviet ME (2001). Discovery of chilling injury. In: Kung, SD; Yang, SF (Eds.) Discoveries in Plant Biology. Singapore: World Sci. Pub. 423448.

Scandalios JG (1993).Oxygen stress and superoxide dismutases. Plant Physiol. 101:7-12.

Seo SG, Shim IS, Usui K, Fujihara S (2007). Analysis of polyamines, 1aminocyclopropane-1-carboxylic acid and their conjugated forms in floral organs of Hibiscus syriacus L. J. Jpn Soc. Hortic. Sci.76:149156.

Serrano M, Pretel MT, Martínez-Madrid MC, Romojaro F, Riquelme F (1998). $\mathrm{CO}_{2}$ treatment of zucchini squash reduces chilling-induced physiological changes. J. Agric. Food Chem. 46:2465-2468.
Silva EAA, Pinho EVRV, Vieira MGGC, Carvalho MLM, Machado JC (2000). Alterações dos padrões de isoenzimas em sementes de milho infectadas por fungos. Pesquisa Agropecuária Brasileira. 35(9):1725-1732.

Silveira V, Floh EIS, Handro W, Guerra MP (2004). Effect of plant growth regulators on the cellular growth and levels of intracellular protein, starch and polyamines in embryogenic suspension cultures of Pinustaeda. Plant tissues organelles culture. 69:233-249.

Silveira V, Santa-Catarina C, Tun NN, Scherer GFE, Handro W, Guerra MP, Floh EIS (2006). Polyamine effects on the endogenous polyamine contents, nitric oxide release, growth and differentiation of embryogenic suspension cultures of Araucáriaangustifólia (Bert) $\mathrm{O}$. Ktze. Plant Sci. 171:91-98.

Sood S, Vyas D, Nagar PK (2006). Physiological and biochemical studies during flower development in two rose species. Sci. Hortic. 108:390-396.

Souza AS (2008). Longevidade de Heliconia psittacorum $\times H$. spathocircinata 'Golden Torch' e H. bilhai em resposta ao uso de reguladores de crescimento.158 f. Tese (Doutorado em Agronomia)Universidade Federal de Viçosa.

Tabor CW, Tabor H (1984). Polyamines. Ann. Rev. Biochem. 53:749790.

Thomashow MF (2001). So what's new in the field of plant cold acclimation. Plant Physiol. 125:89-93.

Vaslier N, Van Doorn WG (2003). Xylem occlusion in bouvardia flowers: evidence for a role of peroxidase and cathecol oxidase. Postharvest $B$ and Technology. 28:231-237.

Vieira MRS, Teixeira da Silva JA, Lima GPP, Vianello F. (2010). Changes in polyamine, total protein and total carbohydrate content and peroxidase activity during the lifetime of chrysanthemum 'Faroe'. Floricult. Ornamental Biotech. 4(1):48-52.

Wang CY, Ji ZL (1989). Effect of low-oxygen storage on chilling injury and polyamines in zucchini squash. Sci Horticul. 39(1):17-19.

Woodson WR, Handa AK (1987). Changes in protein patterns and in vivo proteins synthesis during presenescence and senescence of hibiscus petals. J. Plant Physiol. 128:67-75.

Yang SF, Hoffman NE (1984). Ethylene biosynthesis and its regulation in higher plants. Ann. Rev. Plant Physiol. 35: 155-189.

Zauberman GY, Fuchs S, Akerman M (1985). Peroxidase activity in avocado fruit stored at chilling temperatures. Sci. Hortic. 26:261-265. 